\title{
Risk factors associated with asthma exacerbations in school-age children
}

\author{
Tolga S Yavuz ${ }^{*}$, Ozgur Kartal ${ }^{2}$, Guven Kaya ${ }^{3}$, Mustafa Gulec ${ }^{2}$, Mehmet Saldir ${ }^{3}$, Osman Sener ${ }^{2}$ \\ From 2nd International Severe Asthma Forum (ISAF) \\ Athens, Greece. 13-15 November 2014
}

\begin{abstract}
Background
Acute asthma exacerbation is one of the most frequent emergencies in childhood. Awareness of risk factors related with asthma exacerbation will reduce the morbidity and the mortality of the disease. The aim of this study is to investigate the factors associated with asthma exacerbations in school-age children.
\end{abstract}

\section{Method}

Children who attended to a tertiary outpatient pediatric allergy and asthma department and diagnosed with asthma were enrolled in the study. A questionnaire including demographic features and parameters to determine socioeconomic status were applied. Asthma control status of patients was evaluated according to GINA criteria. Laboratory investigations including complete blood counts with differential, total IgE levels, skin prick tests and pulmonary function tests were also performed.

\section{Results}

A total of 348 children (232 male (66.7\%); with a median age [interquartile range] of 8.0 [6.2-11.1] years were included. $45.9 \%$ of children had aeroallergen sensitization. Asthma was controlled in 138 children (39.7\%), whereas partially controlled and uncontrolled in 45 (12.9\%) and 98 (28.2\%) patients, respectively. 67 patients (19.3\%) were having an asthma exacerbation. The history of ER admittance and asthma exacerbation in the last year was more frequent in children with asthma exacerbation ( $p<0.001$ and $p<0.001$, respectively). Moreover, children with asthma exacerbation were less frequently under regular asthma controller therapy $(\mathrm{p}<0.001)$. Multivariate logistic regression analysis revealed that history of asthma exacerbation in the last

${ }^{1}$ GATA School of Medicine, Department of Pediatric Allergy, Ankara, Turkey Full list of author information is available at the end of the article year (Odds Ratio [Confidence Interval]) (22.47 [9.2854.44]; $\mathrm{p}<0.001)$, lack of regular asthma controller therapy (3.51 [1.22-10.10]; $\mathrm{p}=0.02)$, lack of previous asthma diagnosis (3.34 [1.70-6.57]; $\mathrm{p}<0.001)$ and being overweight $(2.25$ [1.15-4.40]; $\mathrm{p}=0.018)$ were related with asthma exacerbation in school-age children with asthma.

\section{Conclusion}

Awareness of risk factors related with asthma exacerbation may alert physicians who deal with school-age children with asthma and may help prompt and rational interventions in order to prevent asthma exacerbations.

\section{Authors' details}

${ }_{1}^{1}$ GATA School of Medicine, Department of Pediatric Allergy, Ankara, Turkey. ${ }^{2}$ GATA School of Medicine, Department of Adult Allergy, Ankara, Turkey.

${ }^{3}$ GATA School of Medicine, Department of Pediatrics, Ankara, Turkey.

Published: 23 March 2015

\section{doi:10.1186/2045-7022-5-S2-P6}

Cite this article as: Yavuz et al:: Risk factors associated with asthma exacerbations in school-age children. Clinical and Translational Allergy 2015 5(Suppl 2):P6.

Submit your next manuscript to BioMed Central and take full advantage of:

- Convenient online submission

- Thorough peer review

- No space constraints or color figure charges

- Immediate publication on acceptance

- Inclusion in PubMed, CAS, Scopus and Google Scholar

- Research which is freely available for redistribution
C Biomed Central

(c) 2015 Yavuz et al; licensee BioMed Central Ltd. This is an Open Access article distributed under the terms of the Creative Commons Attribution License (http://creativecommons.org/licenses/by/4.0), which permits unrestricted use, distribution, and reproduction in any medium, provided the original work is properly cited. The Creative Commons Public Domain Dedication waiver (http:// creativecommons.org/publicdomain/zero/1.0/) applies to the data made available in this article, unless otherwise stated. 